\author{
Adam Wojtczak ${ }^{1}$ \\ Adam Mickiewicz University, Poznan, Poland \\ Faculty of Theology
}

\title{
Marian Inspirations for the Culture of Encounter according to Pope Francis
}

We live in the world that is becoming 'smaller' and therefore - it seems bringing people together should be easier. ${ }^{2}$ However, this is not the case. Within mankind - as Pope Francis diagnoses - numerous divisions persist. Social diseases, especially ubiquitous individualism, relativism and the lack of awareness of sin cause that humanity is deeply wounded. There is a growing sense of 'spiritual orphanage' ${ }^{3}$ that manifests itself in disappearing experience of bonding and closeness, growing social strangeness and exclusion. ${ }^{4}$

In the face of the crisis that affects the man, the Church cannot remain indifferent. Pope Bergoglio urges Christians: 'We must defend ourselves against

\footnotetext{
${ }^{1}$ Father Adam Wojtczak — born in 1955, priest from the Congregation of Missionary Oblates of Mary Immaculate, dr hab. of theology; prof. of AMU, author of five books: Uczennica i Matka. Wokół chrystocentryzmu mariologii Jana Pawła II; Matka i Królowa. Ku integralnemu i pogłębionemu rozumieniu tytułów maryjnych; Serva Domini. Z maryjnego nauczania Benedykta XVI; Symboliczne inwokacje Litanii loretańskiej. Historia - teologia - kult; Czułe oblicze Matki. Przewodnie motywy mariologii papieża Franciszka, as well as over 80 articles in the field of Mariology and theology of the Eucharist in Polish and foreign magazines; member of the Society of Dogmatic Theologians, Polish Mariological Society and Pontificia Academia Mariana Internationalis; e-mail: adam.wojtczak@oblaci.net. ORCID: 0000-00016431-2116.

2 See Franciszek, Przekaz w stużbie kultury spotkania (Orędzie na XLVIII Światowy Dzień Środków Społecznego Przekazu 2014 roku, 24 czerwca 2014), OsRomPol 35 (2014) 2, p. 6.

${ }^{3}$ Id., Jak w Efezie (Homilia na uroczystość Świętej Bożej Rodzicielki Maryi, 1 stycznia 2017), OsRomPol 38 (2017) 1, p. 14.

${ }^{4}$ See M. Borghesi, Jorge Mario Bergoglio. Biografia intelektualna. Dialektyka i mistyka, thum. D. Chodyniecki, Kraków 2018, pp. 412-414.
} 
the culture of rejection', move "from the culture of exclusion to the culture of encounter' 6 , 'strengthen the culture of encounter", 'be creators of the revolution of tenderness' ${ }^{8}$ Simultaneously, Francis argues that Jesus Himself teaches us the culture of encounter. His love urges us (see 2 Cor 5:14). Faith is the encounter with Him that obliges us to do the same He did: meeting others and helping. ${ }^{9}$ Among other things, the Gospel shows His pity for the widow of Nain and the compassion He showed to a hungry crowd on the day of the loaves multiplication and at the grave of His friend Lazarus when He wept. ${ }^{10}$

Mary, the first disciple of Jesus, also plays an important role in discovering and practising the mysticism of living together, meeting and experiencing communion, as well as supporting one another. Without Her, according to Francis, we cannot understand the spirit of the new evangelization. The Church ministry is characterized by the Marian style: 'whenever we look to Mary, we come to believe once again in the revolutionary nature of love and tenderness. [...] This interplay of justice and tenderness, $[\ldots]$ and concern for others $[\ldots]$ is what makes the ecclesial community look to Mary as a model of evangelization'. ${ }^{11}$

In this paper, I will follow the footsteps of Pope Bergoglio, who in the evangelical scene of the visitation of Mary distinguishes three elements of the encounter: 'Mary goes, Mary meets and Mary rejoices'. ${ }^{12}$ They set the basic structure

${ }^{5}$ Franciszek, Musimy się bronić przed kultura odrzucania (Spotkanie z ludźmi ubogimi, starymi i niepełnosprawnymi, 21 czerwca 2015), OsRomPol 36 (2015) 7-8, p. 28.

${ }^{6}$ Id., Od kultury wykluczenia do kultury spotkania (Spotkanie z członkami Apostolskiego Ruchu Niewidomych i Małej Misji dla Głuchoniemych, 29 marca 2014), OsRomPol 35 (2014) 3-4, p. 40.

${ }^{7}$ Francis, Apostolic journey of His Holiness Pope Francis to Romania (Homily in Bucharest St. Joseph Cathedral, 31 May 2019), http://w2.vatican.va/content/francesco/en/homilies/2019/documents/papa-francesco_20190531_omelia-bucarest-romania.html.

${ }^{8}$ Franciszek, My, chrześcijanie, musimy być twórcami rewolucji czułości (Przemówienie podczas spotkania ekumenicznego w Malmö, 31 października 2016), OsRomPol 37 (2016) 11, p. 12.

9 See id., Kultura spotkania z najbardziej potrzebujacymi (Przesłanie do wiernych w Buenos Aires z okazji święta św. Kajetana, 7 sierpnia 2013), OsRomPol 34 (2013) 10, p. 42.

${ }^{10}$ See id., Kultura spotkania (Homilia w Domu Świętej Marty, 13 września 2016), OsRomPol 37 (2016) 9, pp. 24-25. 'Encouragement to work for «the culture of encounter» in the ordinary way, «just like Jesus did»: not only seeing but looking, not only hearing but listening, not just passing people, but stopping with them, not only by saying «shame, poor people!», but letting compassion overwhelm us; «and also approach, touch and say: 'Don't cry' and give at least a drop of life»' (ibid., p. 24).

${ }^{11}$ Francis, Apostolic Exhortation Evangelii Gaudium. On preaching the Gospel in today's world (24 November 2013), 288 [hereinafter: EG]. http://www.vatican.va/content/francesco/en/ apost_exhortations/documents/papa-francesco_esortazione-ap_20131124_evangelii-gaudium.html [accessed 10.02.2020].

${ }^{12}$ Id., Apostolic journey... 
of reflections about Mary as a promoter of the culture of encounter. ${ }^{13}$ I will also make use of other biblical texts and thoughts of the Pope from Argentina.

\section{'She is our sister on the way' ${ }^{14}$}

According to the Gospel of Saint Luke, Mary, after having received the Annunciation and her fiat in response to the vocation to become the Mother of the Son of God, got up and set off to visit Her cousin Elizabeth, who, being six months pregnant, needed Her help. She was far from considering Herself as someone special and believing that everyone should come to look after Her and serve Her. Although God assured her of His presence and support, many unclear issues remained in Her thoughts and in Her heart. Despite this, She did not lock Herself in the house, did not let Her fear or pride paralyze Her. Mary — as Francis notes was not a person who needed a sofa to feel good, to sit comfortably and safely on it. She was not a 'couch girl!'. ${ }^{15}$ On the way to Elizabeth, She knew no obstacles because 'She let herself be led by the Spirit on the path of faith, towards the destiny of service'. ${ }^{16}$ Neither agitated nor lethargic, She hurried to visit Elizabeth. And from that first day that was Her special feature. A little later she went from Galilee to Bethlehem, where Jesus was born; She fled to Egypt to save the Child from Herod; every year She made a pilgrimage to Jerusalem for the feast of Easter, until the last journey when she followed Her son to Calvary. Also today She is a woman who visits. She accompanies people in dramatic events; protects all those who suffer by defending their rights in the struggle. ${ }^{17}$

13 I omit in the article the analysis of the secret of encounter between man and God, which takes place under the sign of faith. Mary, unlike Zechariah, who doubted, believed and is therefore blessed.

14 Ibid.

15 Franciszek, Rewolucyjna modlitwa Maryi (Orędzie na XXXII Światowy Dzień Młodzieży 2017 roku, 27 lutego 2017), OsRomPol 38 (2017) 3-4, p. 5. 'I like this image of the Virgin', confesses Cardinal J.M. Bergoglio — 'who doesn't waste time getting closer to Her children, meeting them. And this is Jesus' first meeting: the meeting of Jesus in the womb of Mary, the meeting of Mary with Her cousin and with the child who moves with joy for this meeting; the Virgin is in a hurry to meet the needy, in a hurry to take Her motherhood even further, take it to others. She is in a hurry, because She is the mother, She is in a hurry, because She has this Son not for Her own glory, but in the service of humanity' (J.M. Bergoglio, Kazanie z okazji 200-lecia niepodległości krajów Ameryki Łacińskiej w Guadalupe (Guadalupe, 12 grudnia 2011), in: Franciszek / J.M. Bergoglio, Chciałbym Kościoła ubogiego dla ubogich, Kraków 2013, p. 60.

16 EG 287, See Franciszek, Spotkanie dwóch matek jest hymnem radosnego uniesienia w Panu (Anioł Pański, 23 grudnia 2018), OsRomPol 40 (2019) 1, p. 55.

17 See id., Rewolucja czułości (Homilia w sanktuarium Matki Bożej Miłosierdzia w El Cobre, 22 września 2015), OsRomPol 36 (2015) 10, p. 24. 
Marian journeys awaken hearts and incline to 'go outside' 18 to meet others. All Christians are called to the evangelistic exit.

A Church which 'goes forth' - we can read in the Apostolic Exhortation Evangelii Gaudium - is a Church whose doors are open. Going out to others in order to reach the fringes of humanity does not mean rushing out aimlessly into the world. Often it is better simply to slow down, to put aside our eagerness in order to see and listen to others, to stop rushing from one thing to another and to remain with someone who has faltered along the way. ${ }^{19}$

Mary, free of Herself, did not focus on Herself - and She would have a reason! - but She was thinking of those who were more in need at the moment. She argues in this way that one should not cultivate 'spirituality with the label' (I am a Christian $)^{20}$, i.e. worry about oneself but be 'able to go, set out, meet God's children in their real situation and feel compassion over their wounds' ${ }^{21}$ The Pope realizes that some Christians are 'parked Christians, people who have found a good car park in the Church. [...] For them, the Church is a car park, where life is protected and people live with all possible protections' ${ }^{22}$ For this reason, the Pope repeatedly warns that

When the Church is closed, she falls sick, she falls sick. Think of a room that has been closed for a year. When you go into it there is a smell of damp [...]. A Church closed in on herself is the same, a sick Church. The Church must step outside herself. [...] But what happens if we step outside ourselves? The same as can happen to anyone who comes out of the house and onto the street: an accident. But [...] I far prefer a Church that has had a few accidents to a Church that has fallen sick

18 Ibid.

19 EG 46. Before the pontificate Cardinal Bergoglio warned against the perversion of the Church, which 'lives in itself, with itself and for itself' (A. Draguła, Kościót Franciszka, Kościót Benedykta, 'Więź' 56 (2013) 2, pp. 24-25).

${ }^{20}$ Franciszek, Bądźcie myślą i sercem Kościoła wychodzącego (Przemówienie do członków ruchu Komunia i Wyzwolenie, 7 marca 2015), OsRomPol 36 (2015) 3-4, p. 31. 'Going out' — explains the Pope - also means to reject focusing on oneself in all forms, it means to be able to listen to those who are not like us, to learn from everyone with honesty. When we are slaves to self-focus, we ultimately cultivate 'spirituality with the label' ('I am from the Communion and Liberation'). This is a label. And so we will fall into the thousands of traps set by complacency, looking at oneself in the mirror, which leads us to confusion and transformation into ordinary entrepreneurs of some NGO'.

${ }^{21}$ Id., Wyjście jako fundamentalne doświadczenie powołania (Orędzie na Światowy Dzień Modlitw o Powołania, 29 marca 2015), OsRomPol 36 (2015) 5, p. 17.

22 Id., Zakaz parkowania (Homilia w Domu Świętej Marty, 17 January 2017), OsRomPol 38 (2017) 2, p. 46. 
from being closed Go out, go out! [...] In this "stepping out" it is important to be ready for encounter. For me this word is very important. Encounter with others. [...] We must go out to meet them [...] with our faith we must create a "culture of encounter", a culture of friendship, a culture in which we find brothers and sisters, in which we can also speak with those who think differently, as well as those who hold other beliefs, who do not have the same faith [...]. They all have something in common with us: they are images of God, they are children of God. Going out to meet everyone, without losing sight of our own position. ${ }^{23}$

On the way out, it is important that we do not lose our roots, our own identity. Francis teaches that the Church, through its ministry, materializes and 'happens' and that we should have the feeling of being the Church. ${ }^{24}$

All of Mary's journeys have a common feature: 'they were never easy, they required courage and patience'. ${ }^{25}$ Her being with God was not a magic solution to Her problems.

The conclusion of today's Gospel passage recalls it: 'the angel departed from her' (v. 38). He departed - the Pope comments — it is a strong verb. The Angel left the Virgin alone in a difficult situation. She knew the special way in which she would become the Mother of God — the Angel had said so — but the Angel had not explained it to others, only to her. And problems began immediately [...]. But faced with problems, Mary places her trust in God. [...] This is the wise approach: not to live depending on problems - when one ends, another appears! - but by trusting God and entrusting every day to him: here I am! 'Here I am' is the phrase. 'Here I am' is the prayer. ${ }^{26}$

Jesus' Mother did not lose Her heart in the face of life uncertainty, especially when it seemed that nothing was going as it should. She did not get into problems, but bravely faced them, she was able to overcome them. She kept a healthy balance between safety and risk. Her guarantee was only certainty that she was

${ }^{23}$ Francis, Vigil of Pentecost with the ecclesial movements (Saint Peter's Square, Saturday, 18 May 2013), http:/www.vatican.va/content/francesco/en/speeches/2013/may/documents/papafrancesco_20130518_veglia-pentecoste.html [accessed 27.09.2020]; K. Pawlina, Eklezjologia Papieża Franciszka, 'Studia Bobolanum' 1 (2014), pp. 13-14.

24 See K. Pawlina, Eklezjologia..., p. 13.

25 Francis, Apostolic journey...

26 Id., Everything can be done by those who trust in God (Angelus, 8 December 2018), OsRomPol 39 (2018) 12, p. 27: http://www.vatican.va/content/francesco/en/angelus/2018/documents/pa-pa-francesco_angelus_20181208.html [accessed 16.09.2020] 'With generous courage of faith, Mary sought to go beyond Herself [...]. We turn to Her [...] so that the desire to go out and to go with enthusiasm to others will grow' (id., Wyjście..., p. 17). 
carrying a promise. The desire to go out to others was stronger in Her than doubts and difficulties. That is why she knows 'what it means to go uphill, She knows our ways uphill - She is our sister on the way. Experienced in hard work, She knows how to take us by the hand in potholes when we are facing the steepest turns of life'. ${ }^{27}$ Like a good mother, She is close to us so that we never lose courage in the face of life's adversities and our weaknesses. We need Her courage to go out to our neighbors freely, sometimes even against the tide. ${ }^{28}$ Christians - as Francis teaches - must be 'brave', have 'the courage to move forward'. This is true 'Christians often make mistakes; but who promised you that you would never make a mistake in your life. Those who go forward make mistakes, [...] those who stand still make the impression that they do not make mistakes'. Therefore, apart from courage, you need the ability to wait: at the moment when you cannot move forward, because everything is dark, everything is closed, you have to wait patiently. It is about the stability through which it is written that people become 'heirs of promises'. It is 'stability during hard times'. ${ }^{29}$

You should not separate faith from love because they are closely connected. Faith feeds on love. Mary felt 'urged by the love of God, who incarnated in her, and went to an elderly relative'.$^{30}$ The evangelist says that she 'went' (Lk 1:39). It was a gesture of care, She cared more for others than Herself. She knew that love is making its way in small everyday matters. Her mother's love and genius were able to 'transform the animal stable into the house of Jesus, with modest diapers and with great tenderness' ${ }^{31}$ In this way, Mary teaches that the culture of encounter allows us to wander together, with our differences, but also with love. 'True love does not eliminate legitimate differences, but harmonizes them in a superior unity'. 32 'I encourage you', urges Pope Bergoglio,

27 Id., Apostolic journey...

28 See Franciszek, Maryja opiekuje się nami jak dobra mama (Nabożeństwo różańcowe w bazylice Matki Boskiej Większej, 4 maja 2013), OsRomPol 34 (2013), p. 5; id., Tam gdzie jest matka, jest zawsze smak domu (Homilia na liturgiczne wspomnienie Najświętszej Maryi Panny z Guadalupe, 12 grudnia 2017), OsRomPol 38 (2017) 1, p. 24.

${ }^{29}$ Id., Zakaz parkowania ..., p. 47. See id., Adhortacja apostolska "Christus vivit. Do młodych i całego ludu Bożego (24 marca 2019), Poznań 2019, p. 44-45.

${ }^{30}$ Id., Ewangelia spotkania młodych i starszych (Homilia dla ludzi w podeszłym wieku, 28 września 2014), OsRomPol 35 (2014) 10, p. 41.

31 EG 286. See Francis, Apostolic journey...

32 Id., Address of His Holiness. Welcome ceremony and opening of World Youth Day, (Campo Santa María la Antigua, Cinta Costera, Thursday 24 January 2019), http://w2.vatican.va/content/ francesco/en/speeches/2019/january/documents/papa-francesco_20190124_panama-aperturagmg.html; http://w2.vatican.va/content/francesco/en/speeches/2019/january/documents/papa-francesco_20190124_panama-apertura-gmg.html [accessed 14.09.2020] Francis quotes Benedict XVI, Liturgy of vespers on the feast of the conversion of St Paul for the conclusion of prayer for Christian unity (Patriarchal Basilica of Saint Paul Outside the Walls, Wednesday, 25 January 2006), http:// 
to contemplate Mary's love: a caring, dynamic, concrete love [...] full of boldness and totally focused on the gift of oneself. A love full of boldness and focused completely on the gift of self. A Church permeated by these Marian qualities will always be a Church going forth, one that goes beyond her own limits and boundaries to let the grace she has received overflow. If we allow ourselves to be truly touched by Mary's example, we will live out authentically that charity which urges us to love $[\ldots]$ to love those with whom we share our daily life. And we will also love those who may seem hardly lovable in themselves. It is a love that is service and dedication, above all towards the weakest and poorest, love that transforms our faces and fills us with joy. ${ }^{33}$

On the way of going out to others there are periods of fatigue, quiet, persistent and unnoticed self-sacrifice. Mary experienced them, especially during the years spent in Nazareth, when Jesus was growing up. In the face of difficult and painful life events, the response of faith entailed a 'peculiar effort of the heart'. ${ }^{34}$ However, She never lost her peace of heart or was disconsolate. Difficulties were not a reason to say 'no'. She was still involved. Her desire to serve others was stronger than doubts and everyday life problems. It is a model for all those who are not afraid to 'roll up their sleeves' and take on the hardships to open themselves to others. ${ }^{35}$ Only by making many sacrifices to be able to meet can you become creators of the culture of encounter.

It must be accompanied by - the Pope continues - 'a strong sense of hope, regardless of any circumstances that could obscure it or try to extinguish it. Looking at Mary $[\ldots]$, we experience Her and strengthen the space of hope that gives birth and opens the future'. ${ }^{36}$ Mary's whole life was a set of attitudes expressing hope, beginning with the 'yes' said at the time of the Annunciation, through Bethlehem, where Her announced Redeemer was born in poverty, an episode of finding twelve-year-old Jesus lost in Jerusalem, wedding at Cana of Galilee, where She was a mother of hope that made Her watchful and full of concern for human things, at the foot of the cross, where She was a woman of pain and at the same

w2.vatican.va/content/benedict-xvi/en/homilies/2006/documents/hf_ben-xvi_hom_20060125_ conversion-st-paul.html [accessed 4.10.2020].

${ }^{33}$ Francis, The biggest obstacle is fear (Message for the $33^{\text {rd }}$ World Youth Day, 11 February 2018), http://www.vatican.va/content/francesco/en/messages/youth/documents/papa-francesco_20180211_messaggio-giovani_2018.html [accessed 27.09.2020].

${ }^{34}$ Jan Paweł II, Encyklika Redemptoris Mater. O Blogosławionej Maryi Dziewicy wżyciu pielgrzymujacego Kościoła (25 marca 1987), Vatican 1987, p. 17 - quotation for Francis, Odwaga milczenia i sprzeciw wobec triumfalizmu (Homilia na Niedzielę Palmową, 14 kwietnia 2019), OsRomPol 40 (2019) 4-5, p. 5.

${ }^{35}$ See Francis, Apostolic journey...

${ }^{36}$ Ibid. see P. Warchoł, Maryja w nauczaniu papieża Franciszka, 'Salvatoris Mater' 19 (2017), $1-4$, pp. 231-232. 
time a woman of vigilant waiting for a mystery, greater than the pain that was to be fulfilled, to Her maternal presence in the Cenacle of the Pentecost, where She reunited the weak and scared Christ's disciples. ${ }^{37}$ Mary's attitude teaches us to go out to others, even when everything seems meaningless. It supports us in times of darkness, difficulties, discouragement, apparent defeat or real human failures. Mary says to our heart: Arise! Come out to the people, looking ahead, looking at the horizon. ${ }^{38}$ Her Magnificat is also a song of hope for God's people on their way through history. 'This song', notes Pope Bergoglio,

is particularly strong in places where the Body of Christ is suffering the Passion. For us Christians, wherever the Cross is, there is hope, always. If there is no hope, we are not Christian. That is why I like to say: do not allow yourselves to be robbed of hope. May we not be robbed of hope, because this strength is a grace, a gift from God which carries us forward with our eyes fixed on heaven. And Mary is always there, near those communities, our brothers and sisters, she accompanies them, suffers with them, and sings the Magnificat of hope with them. ${ }^{39}$

Mary goes and encourages us to wander with Her and Her example. The one who celebrated the joy of going beyond Herself teaches how to go 'from home to the paths of visitation' ${ }^{40}$, which means that She arouses in us a desire to leave and eagerly go towards others. Francis directs prayers to Her: 'Acting woman, make our hands and feet go «in a hurry» towards others, to bring them mercy and love of Your Son Jesus, and — just like You — to bring the light of the Gospel to the world'. ${ }^{41}$

37 See Franciszek, Ci, którzy potrafia czekać (Homilia podczas Nieszporów w rzymskim klasztorze św. Antoniego Opata, 21 listopada 2013), OsRomPol 35 (2014) 1, pp. 18-19; id., Maryja stała (Audiencja generalna, 10 maja 2017), OsRomPol 38 (2017) 6-7, p. 30.

38 See id., Maryja stała..., p. 30.

39 Francis, 'Magnificat' as a canticle of humble hopes (Homily for the feast of the Assumption of the Blessed Virgin Mary, 15 August 2013), http://www.vatican.va/content/francesco/en/homilies/2013/documents/papa-francesco_20130815_omelia-assunzione.html [accessed 16.09.2020].

${ }^{40}$ Franciszek, Rewolucja czułości..., p. 25. 'When we close our hearts for fear of others, when we build walls and barricades, we end up depriving ourselves of the Good News of Jesus, who shares in the history and the lives of others [...]. Today we feel the need to look one another in the face and acknowledge one another as brothers and sisters, to walk side by side, and to discover and experience with joy and peace the value of fraternity (Francis, Let's ask for the gifts of dialogue and patience (Speech at the Shrine of Our Lady of Mercy in Vilnius, 22 September 2018), http:// w2.vatican.va/content/francesco/en/prayers/documents/papa-francesco_preghiere_20180922_ preghierasantuario-vilnius-lituania.html [accessed 14.09.2020].

${ }_{41}$ Franziskus, Ansprache während Rosenkranzgebets zum Abschluss des Marienmonats (31 V 2013), www.vatican.va [accessed 11.02.2014]. 


\section{The handmaiden of the culture of closeness and tenderness}

The culture of encounter is enabled by closeness and tenderness. The image of the Church as a mother is part of it. 'I dream of a Church - mother' ${ }^{42}$, Francis confessed at the beginning of his pontificate.

For me, the closeness to the Church is fundamental. The Church is a mother, we do not know any mother «by correspondence». Mom gives tenderness, touches, kisses, loves. When the Church, occupied with a thousand matters, neglects closeness, forgets about it and communicates with the faithful only through documents, it is like a mother who contacts her son by writing letters to him'. ${ }^{43}$

Its credibility is confirmed by a tender and compassionate closeness. The culture of encounter must stimulate Christians to experience the miracle of the motherhood of the Church, which seeks, protects and unites its children, i.e. has the courage to hold the meeting and communion. ${ }^{44}$ 'It is obvious to me' - the Pope notes - 'that today the Church needs [...] closeness and intimacy'. ${ }^{45}$ When they are missing, 'the Church loses its true identity and becomes a charity association [...] or some other thing, but not the Church' ${ }^{46}$ Therefore, one should constantly remember that the Church is feminine since 'it is ecclesia, the congregation, it is the bride: it is feminine and it is a mother, it gives birth to the world'. [...] 'It is important $[\ldots]$ that it takes this approach of the bride and mother' ${ }^{47}$, who, with open arms, welcomes all who want it. ${ }^{48}$

Mary remains the model of the motherhood of the Church, 'the most beautiful and most lofty model that there could be'.${ }^{49}$ Her maternal testimony accompanies

${ }^{42}$ A. Spadaro, Serce wielkie i otwarte na Boga. Rozmowa z papieżem Franciszkiem. Z objaśnieniami i komentarzami jezuitów, tłum. Z. Kasprzyk, Kraków 2013, p. 45.

${ }^{43}$ Francesco, Per una Chiesa vicina, OsRomI (1 VIII 2013), p. 7 - quoted after: M. Borghesi, op. cit., p. 399.

${ }^{44}$ See Francis, Apostolic journey... The Mother Church that always has her doors open wide, and her arms open to welcome everyone. Moreover, Mother Church goes out from her own doors to seek with a mother's smile all those who are far and bring them to the mercy of God (id., Three Astonishments (Angelus, 20 December 2015), http://www.vatican.va/content/francesco/en/angelus/2015/documents/papa-francesco_angelus_20151220.html [accessed 14.09.2020].

${ }^{45}$ A. Spadaro, op. cit., p. 43.

${ }^{46}$ Franciszek, Kościól jest kobieta i matka (Homilia w Domu Świętej Marty, 21 maja 2018), OsRomPol 39 (2018) 6, p. 54.

47 Ibid.

${ }^{48}$ See Francis, Three astonishments....

${ }^{49}$ Id., General Audience (St. Peter's Square, Wednesday, 3 September 2014), http://www.vatican.va/content/francesco/en/audiences/2014/documents/papa-francesco_20140903_udienzagenerale.html [accessed 27.09.2020]. 
the Church on the journey from its beginnings. It can be assumed - teaches Francis -

the motherhood of the Church is established in precise continuity with that of Mary, as her continuation in history. [...] by looking at Mary, we discover the most beautiful and most tender face of the Church; and by looking at the Church, we recognize the sublime features of Mary. We Christians are not orphans, we have a mama, we have a mother, and this is great! We are not orphans! The Church is mother, Mary is mother'. ${ }^{50}$

Mary brings a 'home atmosphere' 51 to the Church. It makes the Church 'home for many, mother of all peoples'. ${ }^{52}$ Her look reminds us that closeness and tenderness are essential for faith. Thanks to them, the Church feels a woman and a mother. ${ }^{53}$ Mary helps us to be a motherly Church, a welcoming Church that cares for everyone. ${ }^{54}$ The Holy Spirit, who inspired Her to hurry to serve Elizabeth, encourages us to leave our limitations, closures and particularisms, learn to look beyond appearances and speak well about our fellow men: 'bless them', especially those of our brothers who were exposed to turmoil, deprived not only of home and food, but also the friendship and warmth of the community that would welcome them and help them. ${ }^{55}$

Mary 'reflects God's tenderness' ${ }^{56}$, allows us to feel His closeness and understand 'how much He loves us' ${ }^{57}$, she does not leave, she can do great things also in our weakness. Christian closeness and tenderness result from the fact that since we have been freely gifted by God, everything should be given to others. Mary did not keep 'fullness of grace' from God for Herself, but She became 'Our Lady of Help' ${ }^{58}$ for others, so that the received grace would spill. Thus, She inspires us to meet and, along with meeting, to help. 'We must', urges the Pope, 'be able to meet, create, and build the culture of encounter'. ${ }^{59}$ In Mary, we see that 'humility

\footnotetext{
${ }^{50}$ Ibid.

${ }^{51}$ Franciszek, Matka Boża wnosi do Kościoła atmosferę czutości (Homilia na uroczystość Świętej Bożej Rodzicielki Maryi, 1 stycznia 2019), OsRomPol 40 (2019) 1, p. 20.

52 EG 288.

${ }^{53}$ See Franciszek, Kościót jest kobieta..., p. 54.

${ }^{54}$ See id., Wobec godności osoby wszystko inne jest drugorzędne (Homilia w Campobasso, 5 lipca 2014), OsRomPol 35 (2014) 7, p. 37.

${ }_{55}^{5}$ See Francis, Apostolic journey...; Franciszek, Spotkanie dwóch matek..., p. 55.

${ }^{56}$ See Franciszek, Wstawiennictwo Maryi otwiera na taskę i miłosierdzie Chrystusa (Orędzie na XXIV Światowy Dzień Chorego 2016 roku, 15 września 2015), OsRomPol 36 (2015) 10, p. 9.

${ }^{57}$ See id., Tam gdzie jest matka ..., p. 30.

${ }^{58}$ EG 288.

${ }^{59}$ Franciszek, Kultura spotkania z najbardziej potrzebujacymi..., p. 42. 'What keeps us united? Why are we united? What prompts us to encounter each other? Do you know what keeps us united?
} 
and tenderness are not virtues of the weak but of the strong who need not treat others poorly in order to feel important themselves' ${ }^{60} \mathrm{We}$ are called to experience a revolution of tenderness, 'opening our eyes and hearts to others' ${ }^{61}$, like Mary. Our revolution is achieved through tenderness, which always becomes closeness in the lives of others. Mary teaches to say 'yes' to those who did not remain silent and do not remain silent in the face of the culture of alienation. ${ }^{62}$

The dynamics of a cordial meeting with others makes Mary an example of brotherhood an solidarity. Her look encourages us to become brothers. 'The look of the Mother of God', teaches Francis,

helps us to look at one another as brothers and sisters. Let us look upon one another in a more fraternal way! Mary teaches us to have that gaze which strives to welcome, to accompany and to protect. Let us learn to look at one another beneath Mary's maternal gaze! [...] Let us not be afraid to go out and to look upon our brothers and sisters with Our Lady's gaze. She invites us to be true brothers and sisters. And let us never allow something or someone to come between us and Our Lady's gaze. Mother, grant us your gaze! May no one hide from it! [...]May they not rob us of Mary's gaze, which is full of tenderness, which gives us strength and builds solidarity among us. ${ }^{63}$

The Pope assumes - explains Massimo Borghesi - that a Christian meeting is only possible in an interpersonal relationship, as a reference between 'you' and 'I'. One can only look at 'everyone' if one looks at 'someone'; in fact, because Somebody earlier 'looked at us' and not just 'saw' us. It's usually Mary's look, which allows us to look at Her and through Her look in the face of all those who, united in this look, become people.$^{64}$ Especially in Marian shrines, Mary's homes ${ }^{65}$, as in Cana of Galilee, She offers us Her closeness and helps us discover

It's the certainty of knowing that we have been loved with a profound love that we neither can nor want to keep quiet about; a love that challenges us to respond in the same way: with love. It is the love of Christ that urges us on,' (id., Bądźcie myśla ...).

${ }^{60}$ EG 288.

${ }^{61}$ Franciszek, Rewolucja czułości..., p. 25.

${ }^{62}$ See Francis, Via Crucis (The Way of the Cross with youth at Campo Santa María la Antigua, 25 January 2019), http://w2.vatican.va/content/francesco/en/speeches/2019/january/documents/ papa-francesco_20190125_panama-viacrucis-gmg.html [accessed 14.09.2020].

${ }^{63}$ Id., Pastoral visit to Cagliari. Holy mass at the shrine of "Our Lady of Bonaria" (Homily before the Marian shrine in Bonaria, 22 September 2013), http://www.vatican.va/content/francesco/en/homilies/2013/documents/papa-francesco_20130922_bonaria-cagliari.html [accessed 27.09.2020].

${ }^{64}$ See M. Borghesi, op. cit., p. 422.

${ }^{65}$ See Franciszek, Ona jest Matka każdej zranionej rodziny (Wizyta w sanktuarium Matki Bożej Różańcowej w Madhu, 14 stycznia 2015), OsRomPol 36 (2015) 2, p. 13. 
brotherhood. The pilgrimage to Mary stimulates the awareness that we come as people to our home. We feel called to go together, detach ourselves from our distrust and resentment, not to be afraid of mixing, but to meet and help each other. 'To go on pilgrimage is to participate in that somewhat chaotic sea of people that can give us a genuine experience of fraternity, to be part of a caravan that can together, in solidarity, create history'. ${ }^{66}$ Mary's motherly helps us to see ourselves as beloved children of God's people and to love each other, regardless of the limitations and attitudes of everyone. Mary 'roots us in the Church where unity matters more than diversity, and encourages us to look after each other' ${ }^{67}$

The culture of encounter presupposes getting to know and recognizing the other one. ${ }^{68}$ It is not easy to enter the culture of others, put oneself in the shoes of people so different, understand their thoughts and experiences. Therefore, we often give up the meeting and put up barriers to defend ourselves. In the face of the culture of exclusion and globalization of indifference ${ }^{69}$ promoted today, from Mary we are learning to welcome all those who have been abandoned. It must be done 'with tenderness and without fear: not fearing tenderness' ${ }^{70}$ 'Like Mary', says the Pope, 'we want to be Church, a Church that fosters a culture that welcomes, protects, promotes and integrates; that does not stigmatize, much less indulge in a senseless and irresponsible condemnation of every immigrant as a threat to society'. ${ }^{71}$

Among the victims of the culture of rejection are the elderly. They feel that they are surrounded by cool care and not warmly received. Meanwhile, it has never been and it will never be favourable to break ties between generations, because 'there is no future without this encounter between the old and the young. There is no growth without roots and no flowering without new buds. There is never prophecy without memory, or memory without prophecy. And constant

${ }^{66}$ Francis, Homily at the shrine in Şumuleu Ciuc (Saturday, 1 June 2019), http://w2.vatican.va/ content/francesco/en/homilies/2019/documents/papa-francesco_20190601_omelia-sumuleu-ciucromania.html [accessed 14.09.2020].

67 Id., Matka Boża..., p. 20. See A. Awi Mello, Mit Maria Leben. Ein Gespräch mit Papst Franziskus, Leipzig [2016], p. 172.

68 'The first step is personal dialogue, when the other person speaks and shares his or her joys, hopes and concerns for loved ones, or so many other heartfelt needs' (EG 128).

${ }^{69}$ See ibid., 53-54.

${ }^{70}$ Franciszek, Droga Kościoła jest miłosierdzie i integracja (Homilia dla nowych kardynałów, 15 lutego 2015), OsRomPol 36 (2015) 2, p. 36. 'Mary's look reminds us that tenderness is important for faith as tenderness puts a dam of lukewarmness. Tenderness: Church of tenderness. [...] Mary never points to herself, but to Jesus; and brothers because Mary is a mother' (id., Matka Boża..., p. 20).

${ }^{71}$ Francis, Via Crucis... See id., Homily for the World Day of Migrants and Refugees (Vatican Basilica, Sunday, 14 January 2018), http:/www.vatican.va/content/francesco/en/homilies/2018/ documents/papa-francesco_20180114_omelia-giornata-migrante.html [accessed 20.02.2020]. 
encounter'. ${ }^{72}$ 'That is why' — he adds — 'we want to be the Church of remembrance which appreciates, respects and grants elders the rightful place of guardians of our roots' ${ }^{73}$ To do this, it is necessary to return to the biblical scene of the visitation, in which young Mary meets with older Elizabeth, not only to help her, but also to learn from her the wisdom of life. Mary was able to listen to Her elderly relative, she appreciated her wisdom, which turned out to be valuable to her 'on her way of a woman, a bride and a mother' ${ }^{74}$ In this way, She promotes the culture of meeting young and old people. For the future of the people it is inalienable, because 'the young give strength so that the people can move forward, and the elders strengthen this strength with people's memory and wisdom' ${ }^{75}$ 'It is a miracle raised by the culture of encounter in which no one is rejected or labeled, on the contrary where everyone is wanted because they are necessary [...]. They are not afraid to go together'. ${ }^{76}$

A similar logic of the meeting of young and old is manifested during the sacrifice of Jesus, when two couples meet: young Mary and Joseph with the elders Simeon and Anna. 'Old men', comments the Pope,

have received something from young people, young people are taking something from older people. Mary and Joseph find the roots of the people in the temple, and this is important because God's promise is not fulfilled individually and once, but collectively and throughout history. They also find the roots of faith, because faith is not a concept we learn from a textbook, but the art of living with God, which we learn from the experiences of those who preceded us on the road. And so, two young people, meeting old people, find themselves. And at the end of their days, the two old people welcome Jesus, who is the meaning of their lives. In this event, therefore, the prophecy of Joel is fulfilled: 'your old men will have dreams, and your young men will have visions' (3:1). In this meeting, young people see their mission, and old people fulfill their dreams. All this is done because Jesus is at the center of the encounter. ${ }^{77}$

72 Id., Feast of the Presentation of the Lord on the 22nd World Day for Consecrated Life (Homily on the Feast of the Candlemass, 2 February, 2018), http:/www.vatican.va/content/francesco/en/ homilies/2018/documents/papa-francesco_20180202_omelia-vita-consacrata.html [accessed 14.09.2020].

73 Id., Via Crucis...

74 Franciszek, Ewangelia spotkania..., p. 41.

75 Ibid.

76 Francis, Apostolic journey..., p. 23.

${ }^{77}$ Id., Feast... 'It's good for the elderly to communicate their wisdom to the young; and it's good for the young people to gather this wealth of experience and wisdom, and to carry it forward, not so as to safeguard it in a museum, but to carry it forward addressing the challenges that life brings, to carry it forward for the sake of the respective religious orders and of the whole Church'. 
A real meeting does not end with a greeting, but it engages. Mary, going to Her relative Elizabeth, brought Her not only material help, but also Jesus, who already lived in Her womb, and with Him His closeness and tenderness, which breed and strengthen the culture of encounter. The Church and every individual Christian are like Mary because they are sent to bring Christ and His Gospel to everyone. The Church, Franciszek states, does not carry itself, '...the Church carries Jesus and should be like Mary when she went to visit Elizabeth. If, as a hypothesis, the Church were not to bring Jesus, she would be a dead Church. The Church must bring Jesus, the love of Jesus, the charity of Jesus' ${ }^{78}$ Moreover, Mary, when saying 'do whatever He tells you' (Jn 2:5), tells us to listen to Jesus, talk to Him, learn from Him to go beyond ourselves, to meet others with love, just like He who loved us in deeds. This means, as Evangelii Gaudium teaches, that 'true faith in the incarnate Son of God is inseparable from self-giving, from membership in the community, from service, from reconciliation with others. The Son of God, by becoming flesh, summoned us to the revolution of tenderness'. ${ }^{79}$ It creates the culture of closeness that abandons the logic of exceptions to some and excluding others. God came personally to break the chain of privilege, 'which always begets exclusion, and to inaugurate the tenderness of compassion that begets inclusion, which makes each person shine with the dignity for which he/she was created' ${ }^{80}$

A special place in the pontificate of Francis is occupied by all kinds of the poor. He wants the 'poor Church for the poor'. ${ }^{81}$ The Pope assumes that only starting from tender closeness can we accompany and support them on the path of liberation. The closeness helps the poor make themselves 'at home' 82 in every Christian community. Mary presents this style of encounter and support during the wedding in Cana. She appears as a watchful and concerned woman who notices the problem of the newlyweds: there is no wine. She is not introverted or indifferent, but love stimulates Her to be for others. She discreetly addresses Jesus and presents the problem to Him: 'they have no more wine' (Jn 2:3). ${ }^{83} \mathrm{Her}$ intercessory intervention speeds up Jesus' 'hour', and She turns out to be a providential and creative Mother who takes to heart the problems of others and inter-

78 Franciszek, Sekret żydowskiej dziewczyny (Audiencja generalna, 23 października 2013), OsRomPol 34 (2013) 12, p. 38.

79 EG 88.

${ }^{80}$ Franciszek, Logika spotkania i bliskości (Nieszpory na zakończenie 2016 roku, 31 grudnia 2016), OsRomPol 38 (2017) 1, p. 12. Cf. A. Wojtczak, Maryjne odniesienia dla chrześcijańskiej serdeczności w nauczaniu papieża Franciszka, 'Colloquia Theologica Ottoniana' 1 (2018), p. 255.

81 EG 88. A. Awi Mello analyzes the papal connection between Mary and the poor, op. cit., pp. 90-94.

82 EG 100.

${ }^{83}$ See Franciszek, Wstawiennictwo Maryi otwiera na łaske..., p. 8. 
venes, is able to see difficult times and effectively remedies them. It is necessary to assimilate Her sensitivity and 'imagination in serving the needy, the beauty of devoting Her life to others, without distinguishing or discriminating ${ }^{84}$ The wedding in Cana is repeated in every generation. One should follow Mary and Her example along the 'Cana trail' ${ }^{85}$ We are called to accompany and support the poor. 'Let us not be afraid', urges the Pope, 'to experience the power of tenderness and commitment and complicate one's life for others. And, like Mary, let us stand, let us stand firmly on our feet - with a heart turned to God, brave, helping those who have fallen to stand up, raising the humble spirit, helping to put an end to all oppression situations that make them live as crucified' ${ }^{86}$

The greatest poor are places and people where there is no God or where there is indifference towards Him. False humanism and practical materialism make them feel that they are self-sufficient creators and strive not only to replace God, but also to completely do without Him. ${ }^{87}$ Mary, full of grace, holy and blameless, helps them discover God, the primacy of grace, that is, 'it is God's love that prevents, anticipates and saves' ${ }^{88}$ He never forgets His children, He does not leave them, He can do great things with their weakness. He loves with unconditional and pre-emptive love, because $\mathrm{He}$ is love Himself, and love by its very nature tends to spread and bestow itself.8

The poor include the sick and the lonely. The mother standing persistently under Her Son's cross at Calvary, 'nailed to this cross of misunderstanding and suffering ${ }^{\prime}$, teaches 'to touch the suffering of others" ${ }^{\prime}$, and therefore stands at the cross, not with an armored and closed heart, but with the heart that can accompany, the heart which knows what is tenderness and dedication that treats others with respect, tenderness and understanding. ${ }^{92}$ Tender closeness that becomes

${ }^{84}$ Id., Doświadczajcie konkretnej i troskliwej czułości Matki wszystkich (Homilia w Częstochowie z okazji 1050. rocznicy chrztu Polski, 28 lipca 2016), OsRomPol 37 (2016) 7-8, p. 14.

85 Id., Wielkie bogactwo społeczne (Homilia w parku Los Samanes w Guayaquil, 6 lipca 2015), OsRomPol 36 (2015) 7-8, p. 6. See id., Naszym zadaniem jest budowanie globalnej cywilizacji przymierza (Przemówienie do członków Ruchu „Focolari” w Loppiano, 10 maja 2018), OsRomPol 39 (2018) 6, pp. 10-14.

${ }^{86}$ Id., Trzeba przyjać z miłościa drugiego człowieka (Homilia przed sanktuarium maryjnym w Agłonie, 24 września 2018), OsRomPol 39 (2018) 10, p. 31.

${ }^{87}$ Id., Przezwycięż obojętność i zyskaj pokój (Orędzie na Światowy Dzień Pokoju 2016 roku, 8 grudnia, 2015), OsRomPol 37 (2016) 1, p. 5.

88 Id., Jak miłosierny Samarytanin (Homilia na rozpoczęcie Jubileuszu Miłosierdzia, 8 grudnia 2015), OsRomPol 36 (2015) 12, p. 4.

${ }^{89}$ See id., Bóg robi pierwszy krok (Audiencja generalna, 14 czerwca 2017), OsRomPol 38 (2017) 6-7, pp. 36-38.

90 Id., Trzeba przyjąć z miłością..., p. 31.

91 Ibid.

92 See Francis, Via Crucis... 
compassion is needed. It is not a pity, but 'co-suffering to set free' ${ }^{93}$ Just 'tenderness', explains the Pope, 'is the "key" to understanding the sick. The sick cannot be understood with harshness. Tenderness is the key to understanding them, and is also a precious medicine for their healing. And tenderness passes from the heart to the hands; it passes, with full respect and love. ${ }^{94}$ Mary, giving Jesus' disciples reassurance in the Cenacle, is also a remedy for loneliness and breakup. She is the Mother of consolation, who comforts because She is with those who are alone. She teaches that to comfort, words are not enough, but a sensitive presence is needed, meeting lonely people to share their worries, pains, hopes and frustrations.

In the process of building the culture of encounter, there is sometimes a need for forgiveness that leads to reconciliation. It is not about being 'next to each other' but 'together'. 'Mary', says the Pope from Argentina, 'appears as a woman open to forgiveness, putting aside trauma and distrust' ${ }^{95}$ At Calvary,

Mary became for all of us the Mother of forgiveness. Following Jesus' example and by his grace, she herself could forgive those who killed her innocent Son. For us, Mary is an icon of how the Church must offer forgiveness to those who seek it. The Mother of forgiveness teaches the Church that the forgiveness granted on Golgotha knows no limits. Neither the law with its quibbles, nor the wisdom of this world with its distinctions, can hold it back. The Church's forgiveness must be every bit as broad as that offered by Jesus on the Cross and by Mary at his feet. There is no other way. ${ }^{96}$

The Church must go beyond the harms and wounds of the past to create communion with everyone without succumbing to the temptation to isolate and impose its will. ${ }^{97}$ Like Mary, the Church is called to bridge bridges, overthrow walls, sow reconciliation that leads to heal relationships.

${ }_{93}$ Franciszek, Rewolucja czulości..., p. 25.

${ }^{94}$ Francis, FNOPI (Address to members of the Italian National Federation of Nursing Chambers, 3 March 2018), http://www.vatican.va/content/francesco/en/speeches/2018/march/documents/papa-francesco_20180303_ipasvi.html [accessed 14.09.2020].

${ }_{95}$ Franciszek, Trzeba przyjąć z milościa..., p. 31.

${ }^{96}$ Id., Extraordinary jubilee of mercy (Homily in the Basilica of Saint Mary Major, 1 January 2016), http://www.vatican.va/content/francesco/en/homilies/2016/documents/papa-francesco_20160101_giubileo-omelia-portasanta-smmaggiore.html [accessed 16.09.2020].

${ }^{97}$ See Franciszek, Doświadczajcie..., p. 14. 


\section{The reason for our joy}

Joy is part of the culture of encounter. It is 'a Christian way of expressing oneself' ${ }^{98}$ It leads him/her further and gives the courage to meet others and show them closeness. 'Without joy' — says the Pope -

we remain paralyzed, slaves to our unhappiness. Often problems of faith have little to do with a shortage of means and structures, of quantity, or even the presence of those who do not accept us; they really have to do with a shortage of joy. Faith wavers when it just floats along in sadness and discouragement. When we live in mistrust, closed in on ourselves, we contradict the faith. Instead of realizing that we are God's children for whom he does great things (cf. v. 49), we reduce everything to our own problems. We forget that we are not orphans. In our sadness, we forget that we are not orphans, for we have a Father in our midst, a powerful saviour. ${ }^{99}$

On another occasion, the Pope specifies that 'Father is the source of joy. The Son is its expression and the Holy Spirit arouses it' ${ }^{100}$ Therefore, we assume that being Christians is 'a joy in the Holy Spirit' (Rom 14:17). ${ }^{101}$

'Who is more than Mary full of the Holy Spirit? Who more than She obeys His action?' ${ }^{102}$, asks Franciszek rhetorically. And then he reminds us that God found a special pleasure in Mary. In the Annunciation scene, she was called to rejoice in the fact that God called Her to be the Mother of Christ. Henceforth, all secrets, even the deepest ones, which crossed all limits of reason, were a source of inner joy for Her. 'In fact, our joy is a reflection of Mary's joy'. ${ }^{103}$ That is why, the Pope from Argentina calls Mary the 'Cause of our joy' ${ }^{104}$, who teaches the joy of faith. ${ }^{105}$

${ }_{98}$ Id., Radość chrześcijańska (Homilia w Domu Świętej Marty, 28 maja 2018), OsRomPol 39 (2018) 7, p. 57.

${ }^{99}$ Francis, Apostolic journey...

${ }^{100}$ Franciszek, Dom i matka wszystkich (Orędzie na Światowy Dzień Misyjny 2014, 8 czerwca 2014), OsRomPol 35 (2014), p. 5.

${ }^{101}$ Id., Adhortacja apostolska "Gaudete et exsultate”. O powołaniu do świętości w świecie wspótczesnym (19 marca 2018), Kraków 2018, 122.

${ }^{102}$ Francis, Feast...

${ }^{103}$ Franciszek, Z Chrystusem przeszliśmy ze śmierci do życia (Regina caeli, 6 kwietnia 2015), OsRomPol 36 (2015) 5, p. 29.

${ }^{104}$ Id., Dom i matka wszystkich..., p. 5; id., Doświadczajcie..., p. 14. See A. Wojtczak, Teologiczna wymowa maryjnego tytułu „Przyczyna naszej radości” w ujęciu papieża Franciszka, 'Studia Gnesnensia’ 32 (2018), pp. 109-127.

${ }^{105}$ See Franciszek, Wiara Maryi rozwiazuje „węzet” grzechu (Katecheza podczas spotkania modlitewnego na placu św. Piotra, 12 października 2013), OsRomPol 34 (2013) 12, p. 5. 
In the first place, we discover in Mary the dynamics of the joy of going out to others. Becoming the Mother of the Lord, She hurriedly set off into the mountains of Judea to visit the home of Elizabeth and Zachariah, to share great joy with them. Faith would not have such dynamism if it were devoid of joy. It was the clearest sign of the greatness of Her faith. Who imitates Mary 'moves with joy' ${ }^{106}$ and simultaneously, becomes a harbinger of joy. You cannot stop it. It goes on as it is a 'pilgrim virtue', that is, a gift that travels, that walks the path of life; lengthens and widens it. As a proof that joy is a man's virtue on the way, the Pope invokes the words of Saint Augustine: 'Sing and go!' and comments on them: 'This is Christian joy: a Christian sings with joy and goes and carries this joy. This joy is also sometimes obscured by the cross, but it sings and goes. [...] It is a virtue of momentum and of going forward'.

Mary then points out that true joy comes from God. The Gospel scene of the visitation contains the dynamics of God's visitation. Mary rejoices as She brings Christ to Her relatives. In their home, where there used to be sadness because of the lack of children, now there is joy with the child to be born, who will become a great prophet, forerunner of the Messiah. However, it is only when 'Mary arrives', emphasizes the Pope from Argentina, 'joy overflows and gushes from their hearts, because the invisible but real presence of Jesus fills everything with meaning: life, family, the salvation of the people. Everything!'. ${ }^{107}$ Both mothers, as well as children who they carry in their wombs, almost dance for joy. It is then expressed in selfless love, helping each other and mutual understanding.

It turns out that the true joy you experience in meeting others is not the result of your possessions or favorable circumstances, but comes from deep communion between people. However, at the root of this feeling of joy there is God's presence. Its reason is the awareness that we are accepted and loved by Him. ${ }^{108}$ 'With Christ' — as we can read in Evangelii Gaudium — 'joy is constantly born anew'. ${ }^{109}$ If we feel how much He loves us, then our hearts are 'inflamed' with such joy that it spreads to those we meet. ${ }^{110}$ 'Mary, who goes and meets Elizabeth', the Pope sums up,

${ }^{106}$ Id., Darmo otrzymaliście, darmo dawajcie (Spotkanie z duchowieństwem, zakonnikami, zakonnicami i seminarzystami w sanktuarium w El Quinche, 8 lipca 2015), OsRomPol 36 (2015) $7-8$, p. 21.

${ }_{107}$ Francis, Solemnity of the Assumption of the Blessed Virgin Mary (Angelus, 15 August 2017), http://www.vatican.va/content/francesco/en/angelus/2017/documents/papa-francesco_angelus_20170815.html [accessed 14.09.2020]. 'Bringing Jesus to this house meant bringing [...] full joy (id., Secret... 38).

${ }^{108}$ Franciszek, Bóg zawsze dotrzymuje swoich obietnic (Anioł Pański, 15 grudnia 2013), OsRomPol 35 (2014) 1, p. 56.

109 EG 1.

110 See Franciszek, $W$ domu Maryi (Homilia w sanktuarium maryjnym w Aparecidzie, 24 lipca 2013), OsRomPol 34 (2013) 10, p. 14. 
reminds us where God desired to dwell and live, where his sanctuary is, and where we can feel his heartbeat: it is in the midst of his People. There he is, there he lives, there he awaits us. We can apply to ourselves the prophet's call not to fear, not to let our arms grow weak! For the Lord our God is in our midst; he is a powerful saviour (cf. Zeph 3:16-17) and he is in the midst of his people. This is the secret of every Christian: God is in our midst as a powerful saviour. Our certainty of this enables us, like Mary, to sing and exult with joy. ${ }^{111}$

Jesus' coming through Mary to the home of Elizabeth and Zachariah not only created an atmosphere of joy, but full joy was also expressed in Mary's voice in the Magnificat. Overjoyed, She praises God's greatness. 'This is the secret of joy', Francis points out, 'Mary, small and humble, comes from the greatness of God and, despite Her problems - and there was a considerable number of them - remains joyful because She trusts the Lord in everything. It reminds us that God can always do miracles if we are open to Him and our brothers' ${ }^{112}$ Her canticle becomes the song of all mankind. It helps us understand that everything is a gift of God and encourages us to be able to thank. 'Then' - the Pope assures - 'our joy will be full. Only those who can thank experience full joy'. ${ }^{113}$

Mary, the Mother of forgiveness, also opens us to the joy of forgiveness. It is not only about forgiveness, which is the joy of meeting God and His grace of mercy that transforms everything, but also about brotherly forgiveness. His power is a real antidote to sadness caused by resentment and revenge. Forgiveness opens you to joy and serenity, brings back hope that gives you the capacity for mercy. It is important that, like Mary, we walk the paths of reconciliation and make our lives a humble tool of forgiveness. ${ }^{114}$

\section{$* * *$}

The culture of encounter is one of the favourite themes of Pope Francis' teaching. He calls many times for Christians to go out and meet people. The meeting intensifies 'the ability to love, [...] enlarges the heart'. ${ }^{115}$ Mary is the teacher of such a meeting logic. She not only visited Elizabeth, but still visits many men and women, children and the elderly, the young. She goes, meets and rejoices because She brings something greater than Herself — She brings a blessing. Like Her, we

111 Francis, Apostolic journey...

112 Ibid.

113 Franciszek, Czy umiemy mówić dziękuję? (Homilia na zakończenie Jubileuszu Maryjnego, 9 października 2016), OsRomPol 37 (2016) 10, p. 6. See id., Rewolucyjna modlitwa Maryi..., p. 7; id., Adhortacja apostolska Gaudete et exsultate..., 127.

114 See Francis, Extraordinary jubilee...

115 Franciszek, Kultura spotkania z najbardziej potrzebujacymi..., p. 43. 
are to bring a blessing ${ }^{116}$ : to be promoters of the culture of encounter that denies indifference and divisions, and leads to a revolution of intimacy and tenderness that restore people the joy of life.

\section{Summary}

The culture of encounter is among favourite themes of Pope Francis's teaching. Nowadays, in the face of ever increasing feeling of 'spiritual orphanage', manifested by the disappearance of closeness and tenderness, he calls for Christians to go out and meet with people. At the same time, he points to Mary as the promoter of the culture of encounter. This very article is devoted to Her. I follow in the Pope's footsteps, who distinguishes three elements of a meeting in the Gospel scene of Mary's visit to Elisabeth: 'Mary goes, Mary encounters, Mary rejoices'. These elements define the fundamental structure of the reflections presented here. This is about showing that Mary inspires us to go out to others, to show them closeness and tenderness, which restore the true joy of life.

\section{Keywords}

Mary, the culture of encounter, Pope Francis

\section{Maryjne inspiracje w kulturze spotkania w ujęciu papieża Franciszka}

\section{Streszczenie}

Kultura spotkania należy do ulubionych tematów nauczania papieża Franciszka. W obliczu narastającego współcześnie poczucia „duchowego sieroctwa”, które przejawia się w zanikaniu doświadczenia bliskości i czułości, nawołuje on chrześcijan do wychodzenia i spotykania się z ludźmi. Wskazuje jednocześnie na Maryję jako promotorkę kultury spotkania. Właśnie Jej poświęcony jest artykuł. Podążam w nim za papieżem, który w ewangelicznej scenie nawiedzenia Elżbiety przez Maryję wyróżnia trzy elementy spotkania: „Maryja idzie, Maryja spotyka, Maryja się raduje". Wyznaczają one zasadniczą strukturę przedkładanych refleksji. Chodzi w nich o ukazanie, że Maryja inspiruje nas w wychodzeniu ku innym, okazywaniu im bliskości i czułości, które przywracają radość życia.

\section{Słowa kluczowe}

Maryja, kultura spotkania, Kościół, papież Franciszek

${ }^{116}$ See Francis, Apostolic journey... 


\section{References}

Awi Mello A., Mit Maria Leben. Ein Gespräch mit Papst Franziskus, Leipzig [2016].

Benedict XVI, Liturgy of vespers on the feast of the conversion of St Paul for the conclusion of prayer for Christian unity (Patriarchal Basilica of Saint Paul Outside the Walls, Wednesday, 25 January 2006), http://w2.vatican.va/content/benedict-xvi/en/ homilies/2006/documents/hf_ben-xvi_hom_20060125_conversion-st-paul.html.

Bergoglio J.M., Kazanie z okazji 200-lecia niepodległości krajów Ameryki Łacińskiej w Guadalupe (12 grudnia 2011) [in:] Franciszek/Bergoglio J.M., Chciałbym Kościoła ubogiego dla ubogich, Kraków 2013, s. 60-61.

Borghesi M., Jorge Mario Bergoglio. Biografia intelektualna. Dialektyka i mistyka, tłum. D. Chodyniecki, Kraków 2018.

Draguła A., Kościół Franciszka, Kościót Benedykta, "Więź” 56 (2013) 2, p. 15-25.

Francesco, Per una Chiesa vicina Per una Chiesa vicina. Intervista di Papa a Gerson Camarotti di Globo News, OsRomI 1 VIII 2013, p. 7.

Francis, Address of His Holiness. Welcome ceremony and opening of World Youth Day, Campo Santa María la Antigua, Cinta Costera, Thursday, 24 January 2019), http:// w2.vatican.va/content/francesco/en/speeches/2019/january/documents/papa-francesco_20190124_panama-apertura-gmg.html.

Francis, Apostolic Exhortation Evangelii Gaudium. On preaching the Gospel in today's world (24 November 2013), http:/www.vatican.va/content/francesco/en/apost_ exhortations/documents/papa-francesco_esortazione-ap_20131124_evangelii-gaudium.html.

Francis, Apostolic journey of His Holiness Pope Francis to Romania (Homily in Bucharest St. Joseph Cathedral, 31 May 2019), http:/w2.vatican.va/content/francesco/en/ homilies/2019/documents/papa-francesco_20190531_omelia-bucarest-romania.html.

Francis, Everything can be done by those who trust in God (Angelus, 8 December 2018), http://www.vatican.va/content/francesco/en/angelus/2018/documents/papa-francesco_angelus_20181208.html.

Francis, Extraordinary jubilee of mercy (Homily in the Basilica of Saint Mary Major, 1 January 2016), http://www.vatican.va/content/francesco/en/homilies/2016/documents/papa-francesco_20160101_giubileo-omelia-portasanta-smmaggiore.html.

Francis, Feast of the Presentation of the Lord on the 22nd World Day for Consecrated Life (Homily on the Feast of the Candlemass, 2 February 2018), http://www.vatican. $\mathrm{va} /$ content/francesco/en/homilies/2018/documents/papa-francesco_20180202_omelia-vita-consacrata.html.

Francis, FNOPI (Address to members of the Italian National Federation of Nursing Chambers, 3 March 2018), http:/www.vatican.va/content/francesco/en/speeches/2018/ march/documents/papa-francesco_20180303_ipasvi.html. 
Francis, General Audience (St. Peter's Square, Wednesday, 3 September 2014), http:// www.vatican.va/content/francesco/en/audiences/2014/documents/papa-francesco_20140903_udienza-generale.html.

Francis, Homily at the shrine in Şumuleu Ciuc (Saturday, 1 June 2019), http://w2.vatican. $\mathrm{va} /$ content/francesco/en/homilies/2019/documents/papa-francesco_20190601_omelia-sumuleu-ciuc-romania.html.

Francis, Homily for the World Day of Migrants and Refugees (Vatican Basilica, Sunday, 14 January 2018), http:/www.vatican.va/content/francesco/en/homilies/2018/documents/papa-francesco_20180114_omelia-giornata-migrante.html.

Francis, Let's ask for the gifts of dialogue and patience (Speech at the Shrine of Our Lady of Mercy in Vilnius, 22 September 2018), http://w2.vatican.va/content/francesco/en/ prayers/documents/papa-francesco_preghiere_20180922_preghierasantuario-vilnius-lituania.html.

Francis, 'Magnificat' as a canticle of humble hopes (Homily for the feast of the Assumption of the Blessed Virgin Mary, 15 August 2013), http:/www.vatican.va/content/ francesco/en/homilies/2013/documents/papa-francesco_20130815_omelia-assunzione.html.

Francis, Pastoral visit to Cagliari. Holy mass at the shrine of "Our Lady of Bonaria" (Homily before the Marian shrine in Bonaria, 22 September 2013), http://www.vatican.va/content/francesco/en/homilies/2013/documents/papa-francesco_20130922_ bonaria-cagliari.html.

Francis, Solemnity of the Assumption of the Blessed Virgin Mary (Angelus, 15 August 2017), http://www.vatican.va/content/francesco/en/angelus/2017/documents/papa-francesco_angelus_20170815.html.

Francis, The biggest obstacle is fear (Message for the $33^{\text {rd }}$ World Youth Day, 11 February 2018), http:/www.vatican.va/content/francesco/en/messages/youth/documents/papa-francesco_20180211_messaggio-giovani_2018.html.

Francis, Three Astonishments (Angelus, 20 December 2015), http://www.vatican.va/content/francesco/en/angelus/2015/documents/papa-francesco_angelus_20151220.html.

Francis, Via Crucis (The Way of the Cross with youth at Campo Santa María la Antigua, 25 January 2019), http://w2.vatican.va/content/francesco/en/speeches/2019/january/ documents/papa-francesco_20190125_panama-viacrucis-gmg.html.

Francis, Vigil of Pentecost with the ecclesial movements (Saint Peter's Square, Saturday, 18 May 2013), http://www.vatican.va/content/francesco/en/speeches/2013/may/documents/papa-francesco_20130518_veglia-pentecoste.html

Franciszek, Adhortacja apostolska Christus vivit. Do młodych i całego ludu Bożego (25 marca 2019), Poznań 2019.

Franciszek, Adhortacja apostolska Gaudete et exsultate. O powołaniu do świętości w świecie wspótczesnym (19 marca 2018), Kraków 2018.

Franciszek, Bądźcie myśla i sercem Kościoła wychodzacego (Przemówienie do członków ruchu Komunia i Wyzwolenie, 7 marca 2015), OsRomPol 36 (2015) 3-4, pp. 30-32. 
Franciszek, Bóg robi pierwszy krok (Audiencja generalna, 14 czerwca 2017), OsRomPol 38 (2017) 6-7, pp. 36-38.

Franciszek, Bóg zawsze dotrzymuje swoich obietnic (Anioł Pański, 15 grudnia 2013), OsRomPol 35 (2014) 1, p. 56.

Franciszek, Ci, którzy potrafią czekać (Homilia podczas Nieszporów w rzymskim klasztorze św. Antoniego Opata, 21 listopada 2013), OsRomPol 35 (2014) 1, pp. 18-19.

Franciszek, Czy umiemy mówić dziękuję? (Homilia na zakończenie Jubileuszu Maryjnego, 9 października 2016), OsRomPol 37 (2016) 10, pp. 5-6.

Franciszek, Darmo otrzymaliście, darmo dawajcie (Spotkanie z duchowieństwem, zakonnikami, zakonnicami i seminarzystami w sanktuarium w El Quinche, 8 lipca 2015), OsRomPol 36 (2015) 7-8, pp. 17-22.

Franciszek, Dom i matka wszystkich (Orędzie na Światowy Dzień Misyjny 2014, 8 czerwca 2014), OsRomPol 35 (2014) 7, pp. 4-5.

Franciszek, Doświadczajcie konkretnej i troskliwej czułości Matki wszystkich (Homilia w Częstochowie z okazji 1050. rocznicy chrztu Polski, 28 lipca 2016), OsRomPol 37 (2016) 7-8, pp. 13-14.

Franciszek, Droga Kościoła jest miłosierdzie i integracja (Homilia dla nowych kardynałów, 15 lutego 2015), OsRomPol 36 (2015) 2, pp. 34-36.

Franciszek, Ewangelia spotkania młodych i starszych (Homilia dla ludzi w podeszłym wieku, 28 września 2014), OsRomPol 35 (2014) 10, pp. 40-41.

Franciszek, Jak mama (Audiencja generalna, 3 września 2014), OsRomPol 35 (2014) 10, p. $45-46$.

Franciszek, Jak miłosierny Samarytanin (Homilia na rozpoczęcie Jubileuszu Miłosierdzia, 8 grudnia 2015), OsRomPol 36 (2015) 12, pp. 4-5.

Franciszek, Jak w Efezie (Homilia na uroczystość Świętej Bożej Rodzicielki Maryi, 1 stycznia 2017), OsRomPol 38 (2017) 1, pp. 13-15.

Franciszek, Kościót jest kobietą i matka (Homilia w Domu Świętej Marty, 21 maja 2018), OsRomPol 39 (2018) 6, pp. 53-54.

Franciszek, Kultura spotkania (Homilia w Domu Świętej Marty, 13 września 2016), OsRomPol 37 (2016) 9, pp. 24-25.

Franciszek, Kultura spotkania z najbardziej potrzebujacymi (Przesłanie do wiernych w Buenos Aires z okazji święta św. Kajetana, 7 sierpnia 2013), 34 (2013) 10, pp. 42-43.

Franciszek, Logika spotkania i bliskości (Nieszpory na zakończenie 2016 roku, 31 grudnia 2016), OsRomPol 38 (2017) 1, pp. 11-13.

Franciszek, Maryja opiekuje się nami jak dobra mama (Nabożeństwo różańcowe w bazylice Matki Boskiej Większej, 4 maja 2013), OsRomPol 34 (2013) 7, pp. 4-6.

Franciszek, Maryja stała (Audiencja generalna, 10 maja 2017), OsRomPol 38 (2017) 6-7, pp. 29-30.

Franciszek, Matka Boża wnosi do Kościoła atmosferę czułości (Homilia na uroczystość Świętej Bożej Rodzicielki Maryi, 1 stycznia 2019), OsRomPol 40 (2019) 1, pp. 19-21. 
Franciszek, Musimy się bronić przed kultura odrzucania (Spotkanie z ludźmi ubogimi, starymi i niepełnosprawnymi, 21 czerwca 2015), OsRomPol 36 (2015) 7-8, pp. 28-29.

Franciszek, My, chrześcijanie, musimy być twórcami rewolucji czułości (Przemówienie podczas spotkania ekumenicznego w Malmö, 31 października 2016), 37 (2016) 11, pp. 11-12.

Franciszek, Naszym zadaniem jest budowanie globalnej cywilizacji przymierza (Przemówienie do członków Ruchu „Focolari” w Loppiano, 10 maja 2018), OsRomPol 39 (2018) 6, pp. 10-14.

Franciszek, Od kultury wykluczenia do kultury spotkania (Spotkanie z członkami Apostolskiego Ruchu Niewidomych i Małej Misji dla Głuchoniemych, 29 marca 2014), 35 (2014) 3-4, pp. 40-41.

Franciszek, Odwaga milczenia i sprzeciw wobec triumfalizmu (Homilia na Niedzielę Palmową, 14 kwietnia 2019), OsRomPol 40 (2019) 4-5, pp. 4-5.

Franciszek, Ona jest Matka każdej zranionej rodziny (Wizyta w sanktuarium Matki Bożej Różańcowej w Madhu, 14 stycznia 2015), OsRomPol 36 (2015) 2, pp. 13-14.

Franciszek, Przekaz w stużbie kultury spotkania (Orędzie na XLVIII Światowy Dzień Środków Społecznego Przekazu 2014 roku, 24 stycznia 2014), OsRomPol 35 (2014) 2, pp. 6-8.

Franciszek, Przezwycięż obojętność i zyskaj pokój (Orędzie na Światowy Dzień Pokoju 2016 roku, 8 grudnia 2015), OsRomPol 37 (2016) 1, pp. 4-10.

Franciszek, Radość chrześcijańska (Homilia w Domu Świętej Marty, 28 maja 2018), OsRomPol 39 (2018) 7, pp. 57-58.

Franciszek, Rewolucja czułości (Homilia w sanktuarium Matki Bożej Miłosierdzia w El Cobre, 22 września 2015), OsRomPol 36 (2015) 10, pp. 24-25.

Franciszek, Rewolucyjna modlitwa Maryi (Orędzie na XXXII Światowy Dzień Młodzieży 2017 roku, 27 lutego 2017), OsRomPol 38 (2017) 3-4, pp. 4-8.

Franciszek, Sekret żydowskiej dziewczyny (Audiencja generalna, 23 października 2013), OsRomPol 34 (2013) 12, pp. 37-38.

Franciszek, Spotkanie dwóch matek jest hymnem radosnego uniesienia w Panu (Anioł Pański, 23 grudnia 2018), OsRomPol 40 (2019) 1, pp. 54-55.

Franciszek, Tam gdzie jest matka, jest zawsze smak domu (Homilia na liturgiczne wspomnienie Najświętszej Maryi Panny z Guadalupe, 12 grudnia 2016), OsRomPol 38 (2017) 1, pp. 23-25.

Franciszek, Trzeba przyjąć z miłościa drugiego człowieka (Homilia przed sanktuarium maryjnym w Agłonie, 24 września 2018), OsRomPol 39 (2018) 10, pp. 31-32.

Franciszek, Trzy zdumienia (Anioł Pański, 20 grudnia 2015), OsRomPol 37 (2016) 1, pp. $50-51$.

Franciszek, $W$ domu Maryi (Homilia w sanktuarium maryjnym w Aparecidzie, 24 lipca 2013), OsRomPol 34 (2013) 10, pp. 13-15. 
Franciszek, Wiara Maryi rozwiąuje ,węzet” grzechu (Katecheza podczas spotkania modlitewnego na placu św. Piotra, 12 października 2013), OsRomPol 34 (2013) 12, pp. 4-5.

Franciszek, Wielkie bogactwo spoteczne (Homilia w parku Los Samanes w Guayaquil, 6 lipca 2015), OsRomPol 36 (2015) 7-8, pp. 6-8.

Franciszek, Wobec godności osoby wszystko inne jest drugorzędne (Homilia w Campobasso, 5 lipca 2017), OsRomPol 35 (2014) 7, pp. 36-37.

Franciszek, Wstawiennictwo Maryi otwiera na łaskę i miłosierdzie Chrystusa (Orędzie na XXIV Światowy Dzień Chorego 2016 roku, 15 września 2015), OsRomPol 36 (2015) 10 , pp. 8-10.

Franciszek, Wyjście jako fundamentalne doświadczenie powołania (Orędzie na Światowy Dzień Modlitw o Powołania, 29 marca 2015), OsRomPol 36 (2015) 5, pp. 16-17.

Franciszek, Z Chrystusem przeszliśmy ze śmierci do życia (Regina caeli, 6 kwietnia 2015), OsRomPol 36 (2015) 5, pp. 28-29.

Franciszek, Zakaz parkowania (Homilia w Domu Świętej Marty, 17 stycznia 2017), OsRomPol 38 (2017) 2, pp. 46-47.

Franziskus, Ansprache während Rosenkranzgebets zum Abschluss des Marienmonats (31 V 2013), www.vatican.va.

Jan Paweł II, Encyklika Redemptoris Mater. O Błogosławionej Maryi Dziewicy w życiu pielgrzymującego Kościoła (25 marca 1987), Vatican 1987.

Pawlina K., Eklezjologia papieża Franciszka, "Studia Bobolanum” 1 (2014), pp. 13-20.

Spadaro A., Serce wielkie i otwarte na Boga. Rozmowa z papieżem Franciszkiem. Z objaśnieniami i komentarzami jezuitów, tłum. Z. Kasprzyk, Kraków 2013.

Warchoł P., Maryja w nauczaniu papieża Franciszka, "Salvatoris Mater" 19 (2017) 1-4, pp. 216-237.

Wojtczak A., Maryjne odniesienia dla chrześcijańskiej serdeczności w nauczaniu papieża Franciszka, "Colloquia Theologica Ottoniana” 1 (2018), pp. 245-265.

Wojtczak A., Teologiczna wymowa maryjnego tytułu „Przyczyna naszej radości” w ujęciu papieża Franciszka, "Studia Gnesnensia” 32 (2018), pp. 109-127. 